\title{
Wawasan Nusantara : Sebagai Satu Kesatuan, Politik, Ekonomi, Social, Budaya, Dan Hankam
}

\author{
Nine Wahyu Agustina \\ IIK STRADA INDONESIA \\ Ninewahyu7@gmail.com
}

\begin{abstract}
ABSTRAK
Wawasan Nusantara memiliki arti cara pandang bangsa Indonesia tentang diri dan lingkungannya berdasarkan pancasila dan UUD 1945. Aspek yang terdapat pada Wawasan Nusantara yaitu fisik atau wilayah dan social. Sedangkan social yaitu bergantung pada aspek politik, ekonomi, social, budaya dan Hankam yang sedang berlangsung saat ini. Ekonomi dan politik berada sejajar karena hukum seharusnya tidak bisa dikendalikan oleh ekonomi maupun politik, ekonomi, politik dan Hukum, ketiga aspek tersebut tidak sembarangan dijadikan aspek tetapi mempunyai makna, contoh hukum yaitu mengatur Negara menjadi tertib, ekonomi yaitu berkaitan dengan tujuan Negara atau kesejahteraan, sedangkan politik yaitu berkaitan dengan kekuasaan. Antara kondisi fisik dan social pasti akan terjadi perbedaan, perbedaan itu memang di perlukan oleh wawasan Nusantara agar terwujudnya kesatuan.
\end{abstract}

Kata Kunci : Wawasan Nusantara, Satu Kesatuan, Politik, Ekonomi, Sosial, Budaya, Hankam

\section{Latar Belakang}

Wawasan Nusantara adalah pola pandang atau sudut pandang yang meliputi secara keseluruhan atau memandang segala sesuatu dari sudut pandang global dalam nusantara dalam mementingkan kepentingan nasional. Wawasan nusantara sangat penting apalagi saat ini perkembangan teknologi dan komunikasi begitu sangat cepat berubah. Wawasan nusantara dapat dijadikan filter dalam menentukan kebijakan para masyarakat. Apakah untuk bisnis, poltik bahkan untuk social kemasyarakatan. Sebagai warga Negara tentunya siapun akan menginginkan bangsa ini adalah tempat paling aman dan terlindungi. Di dalam bangsa Indonesia ini kita hidup berkedaulatan Indonesia yang diakui di mata dunia.

Namun banyak dari kita lupa bahwa rakyat yang hidup di Indonesia bukan hanya kita. Namun terdiri dari jutaan warga yang berbeda namun memiliki keinginan yang sama. Tidak mudah bagi setiap orang harus merasa cukup dengan saat ini atau apa adanya. Apalagi terlebih kita telah melihat ketimpangan terjadi misalnya adanya perlakuan khusus terhadap pelanggar hukum yang sama berat dalam kehidupan seperti 
kecerdasan dalam berwawasan nusantara sangat dibutuhkan. Untuk tetap berpikir positif menanggapi suatu hal tidak saja membutuhkan kesabaran tetapi pemahaman akan berwawasan yang tinggi, sebaliknya jika satu orang saja yang tidak memiliki wawasan nusantara maka yang akan kena dampaknya semua orang.contohnya pemikiran bahwa wawasan nusantara bukan saja sekedar memikirkan pemerintah namun dalam rangka memberikan kebaikan pada diri kita sendiri. Dengan menyadari dan memahami wawasan nusantara segala hal yang terjadi dalam bangsa Indonesia ini dapat diselsaikan. Segala sesuatu telah diatur dalam tatanan hukum social dan politik.

\section{Rumusan Masalah}

Dari Latar Belakang yang dapat dirumuskan Masalah-Masalah Sebagai Berikut:

1. Mengapa berwawasan musantara itu sangat penting dalam kehidupan ?

2. Apa dampaknya jika kita tidak memiliki wawasan nusantara?

3. Apa manfaat dan tujuan memiliki wawasan nusantara dalam kehidupan?

\section{Kajian Pustaka}

secara etimologi Wawasan Nusantara terdiri dari dua kata, yaitu wawasan dan nusantara. wawasan adalah cara pandang seseorang atau bangsa, sebagai salah satu aspek dari falsafah hidup. Makna wawasan juga sebagai pantulan (refleksi) dan pancaran dari falsafah hidup, yang berisi asas-asas, metode dan isi cita-cita Nusantara berasal dari dua kata yakni nusa berati pulau. Berupa pulau-pulau yang terletak diantara dua benua (Asia dan Australia) serta dua samudera (pasifik dan hindia/Indonesia). Kemudian kata antara diartikan sebagai tanah air indonesi, yaitu kesatuan wilayah perairan dan gugusan pulau-pulau yang terletak diantara dua samudera pasifik dan hindia/Indonesia dan dua benua asia dan Australia

Menurut Syarbani dan Wahid (2015 : 179) wawasan nusantara diartikan sebagai cara pandang bangsa Indonesia tentang diri dan lingkungannya berdasarkan ide nasionalnya yang dilandasi pancasila dan Undang-Undang Dasar 1945, yang merupakan aspirasi bangsa indonsia yang merdeka, berdaulat, bermartabat, serta menjiwai tata hidup dan tindak kebijaksanaanya dalam mencapai tujuan perjuangan nasional. Wawasan nusantara mencangkup empat pokok perwujudan Negara kepulauan Nusantara sebagai satu kesatuan wilayah, yaitu satu kesatuan politik,satu kesatuan ekonomi, satu kesatuan social budaya dan satu kesatuan pertahanan keamanan (HANKAM). Wawasan nusantara kemudian dijadikan wawasan pembangunan dalam ketetapan MPR No.IV/MPR/1973 tentang garis-garis besar haluan Negara (GBHN). 
Implementasi Wawasan Nusantara, wawasan nusantara sebagai wawasan nasional digunakan untuk mewujudkan tujuan dan cita-cita Negara Kesatuan Republik Indonesia dalam membangun bangsa dan Negara, yang merdeka, berdaulat dan bermartabat, dalam satu kesatuan wilayah nusantara. Wawasan Nusantara memberikan pedoman pada pencapaian tujuan nasional yang telah dirumuskan dalam pembukaan UndangUndang Dasar 1945. Satu kesatuan atau integrasi tercemin pada perwujudan kepulauan nusantara sebagai satu kesatuan politik, ekonomi, social budaya dan HANKAM.

\section{Pembahasan}

Wawasan nusantara mempunyai konsepsi yang sangat utuh untuk diimplemantasikan dalam kehidupan berbangsa dan bernegara. Wawasan nusantara dipandang sebagai suatu metode yang tepat dalam menyatukan atau mengintegrasikan wilayah, bangsa dan Negara Indonesia. Sehingga wawasan nusantara mampu menciptakan pandangan bahwa Indonesia merupakan satu kesatuan nusantara.

Ada beberapa macam wawasan nusantara yaitu sebagai berikut :

a. Wawasan Nusantara Sebagai Satu Kesatuan Politik

Implementasi wawasan nusantara dalam kehidupan politik akan menciptakan iklim penyelenggaraan Negara yang sehat dan dinamis. Hal tersebut tampak dalam pemerintahan yang kuat, bersih, aspiratif dan terpercaya yang dibangun sebagai penjelmaan dari kedaulatan rakyat. Hal ini mengandung makna sebagai berikut :

a. Bahwa kedaulatan wilayah nasional dengan segala isi dan kekayaanya merupakan satu kesatuan wilayah, wadah, ruang lingkup dan kesatuan matra seluruh bangsa serta menjadi modal dan milik bersama bangsa.

b. Bahwa bangsa Indonesia yang terdiri dari berbagai suku bangsa dan berbicara dalam berbagai bahasa daerah serta memeluk dan menyakini berbagai agama dan kepercayaan terhadap Tuhan Yang Maha Esa hrus merupakan satu kesatuan bangsa yang bulat dalam arti yang seluas-luasnya.

c. Bahwa bangsa Indonesia yang hidup berdampingan dengan bangsa lain ikut menciptakan ketertiban dunia yang berdasarkan kemerdekaan, perdamaian abadi dan keadilan social melalui politik luar negeri bebas aktif serta diabadikan menuju kepentingan nasional.

Wawasan Nusantara Sebagai Satu Kesatuan Ekonomi 
Implementasi wawasan nusantara dalam kehidupan ekonomi akan menciptakan tatanan ekonomi yang benar-benar menjamin pemenuhan dan peningkatan kesejahteraan dan kemakmuran rakyat secara adil dan merata. Pada aspek ekonomi juga mencerminkan tanggung jawa pengelolaan sumber daya alam yang memperhatikan kebutuhan masyarakat antar daerah secara timbal balik serta kelestarian sumber daya alam itu sendiri. Hal ini mengandung makna :

a. Bahwa kenyataan wilayah nusantara baik potensial maupun efektif adalah modal dan milik bersama bangsa. Bahwa keperluan hidup sehari-hari harus tersedia merata di seluruh wilayah tanah air.

b. Bahwa tingkat perkembangan ekonomi harus serasi diseluruh daerah, tanpa meninggalkan ciri khas yang ada di daerah dalam pengembangan kehidupan ekonominya.

c. Bahwa kehidupan perekonomian di seluruh wilayaah nusantara merupakan satu kesatuan ekonomi yang diselenggarakan sebagai usaha bersama atas asas kekeluargaan dan ditujuan bagi sebesar-besarnya kemakmuran rakyat.

Wawasan Nusantara Sebagai Satu Kesatuan Social Budaya

Implementasi wawasan nusantara dalam kehidupan social Budaya, Implementasi ini menciptakan kehidupan masyarakat dan bangsa yang rukun dan bersatu tanpa membedakan suku, bangsa, asal usul daerah, agama atau kepercayaan serta golongan berdasarkan status social. Budaya Indonesia tidak menolak nilai-nilai budaya asing asal tidak bertentangan dengan nilai budaya bangsa sendiri dan hasilnya dapat dinikmati. Hal ini mengandung makna sebagai berikut :

a. Bahwa masyarakat Indonesia adalah satu, peri kehidupan bangsa harus merupakan kehidupan bangsa yang serasi dengan terdapatnya tingkat kemajuan yang sama, merata dan seimbang serta adanya keselarasan khidupan yang sesuai dengan tingkat kemajuan bangsa.

b. Bahwa budaya Indonesia pada hakikatnya adalah satu, sedangkan corak ragam budaya yang ada menggambarkan kekayaan budaya bangsa yang menjadi modal dan landasan pembangunan budaya bangsa keseluruhannya, dengan tidak menolak budaya lain yang tidak bertentanan dengan nilai budaya bangsa, yang hasilnya-hasilnya dapat dinikmati oleh bangsa.

Wawasan Nusantara Sebagai Satu Kesatuan Pertahanan Dan Keamanan

Implemantasi wawasan nusantara dalam kehidupan pertahanan dan keamanan 
akan membentuk sikap bela Negara. kesadaran dan sikap cinta tanah air dan bangsa serta bela Negara ini menjadi modal utama yang akan menggerakkan partisipasi setiap warga Negara Indonesia dalam menghadapi setiap bentuk ancaman. Hal ini mengandung makna sebagai berikut :

a. Bahwa ancaman terhadap satu pulau atau satu daerah pada hakikatnya merupakan ancaman terhadap seluruh bangsa dan Negara

b. Bahwa tiap-tiap warga Negara mempunyai hak dan kewajiban yang sama dalam rangka pembelaan Negara dan bangsa.

5. Kesimpulan

Berdasarkan penjelasan diatas, maka dapat disimpulkan bahwa wawasan nusantara berfungsi sebagai wawasan pembangunan. Bahwa pembangunan nasional hendaknya mencangkup pembangunan dalam bidak politik, ekonomi, social budaya dan pertahanan keamanan (HANKAM) secara terpadu, utuh dan menyeluruh.

\section{Daftar Pustaka}

Nusantara, A. P. W. MODUL 6 WAWASAN NUSANTARA. PENDIDIKAN KEWARGANEGARAAN, 100.

https://scholar.google.co.id/scholar?hl=id\&as_sdt=0\%2C5\&q=wawasan+nusantara\&oq =\#d=gs_qabs\&u=\%23p\%3DKWOILuewYgwJ

Ilyasa, A. (2021, June). Wawasan Nusantara. In UNUSIA CONFERENCE (Vol. 1, No. 1, pp. 227-238).

https://scholar.google.co.id/scholar?hl=id\&as_sdt=0\%2C5\&q=wawasan+nusantara\&oq =\#d=gs_qabs\&u=\%23p\%3DvPguo2tY7D4J

Siyoto, S., \& Sodik, M. A. (2015). Dasar metodologi penelitian. Literasi Media Publishing. https://scholar.google.co.id/scholar?hl=id\&as_sdt=0\%2C5\&q=muhammad+ali+sodik\&oq=\#d=g s_qabs\&u=\%23p\%3DjGF7Wz2n5JkJ

Agustina, N. W. (2021). Arti Pentingnya Toleransi Antar Agama Dalam Persatuan Dan kesatuan Bangsa Indonesia.

https://scholar.google.com/scholar?hl=id\&as_sdt=0\%2C5\&q=Arti+Pentingnya+Toleransi+Antar +Agama+Dalam+Persatuan+Dan+kesatuan+Bangsa+Indonesia\&btnG=\#d=gs_qabs\&u=\%23p\%3 De-nglyusaVQJ 